\title{
Errors in Translating Articles from English into Thai: Translation Process or Grammatical Knowledge
}

\author{
Palarak Chaiyo, Ed.D \\ * Faculty of Liberal Arts, Rajamangala University of Technology Suvarnabhumi, Thailand \\ DOI: 10.29322/IJSRP.10.07.2020.p10380 \\ http://dx.doi.org/10.29322/IJSRP.10.07.2020.p10380
}

\begin{abstract}
This research aimed to analyze language errors, causes of errors in article translation from English in to Thai and find out the guidance solutions to reduce language errors. The sampling group was 30 students studying in Translation English into Thai course. The data was collected from 60 papers of assignments related to 2 articles with scientific content and arts and cultural content. The research tools were an Analyzation Form of Translation Error and Questionnaire about Students' Translation Processes. The result presented that the main cause of errors was not only the students' grammatical knowledge but also the translation process. Moreover, back ground knowledge, the length of text and translation period were minor factors. The solutions were suggested in the students' points of view due to English grammatical review, concentration in process of translation, doing back ground research of source text and time management.
\end{abstract}

Index Terms- Errors in Translation, Translation English into Thai, Article Translation

\section{INTRODUCTION}

\subsection{A state of significance and research problem}

We, at the present, are in the multicultural and multilingual society that effective, efficient, and empathetic communication between languages and cultures are in demands. Therefore, translation plays the prominent roles in communication in all dimensions such as international trading, tourism, academic, and etc. It is a very serious and prominent responsibility of translators to transform the correct message from the source text (ST) to the target text (TT) for avoiding any problems causing from mistakes or discrepancies in communication. [1] The main purpose of Bachelor of Arts in English for International Communication Program revised in 2011 is to enhance the students' English communication skills with the situations or scenarios that support their learning and practicing English language in all aspects: grammatical knowledge, reading, writing, listening, speaking, translation, culture and applications. [2] Based on the curriculum structure, the students are required to study basic core courses in specific sequence from grammatical foundation to the advanced ones. Translation English into Thai is a compulsory subject in the basic core courses which is focus on an improvement of the students' multi-skills of communication in both of English and Thai language with the means of translation. An efficient translator can be a matter of the student's personal preference in their future career. [3]
However, the learning results of our students were revealed in contrast. The possible reason is translation is complicated, the translators have to be skillful in interpreting correct meaning and purpose, maintain mood and style of ST to TT. It was found that the achievements of students enrolled in English into Thai Translation course during the 2015-2017 academic year were quite low and tended to keep lower. $39.32 \%$ of them got the grade lower than $C(<60 \%)$ especially in 2016 and 2017 academic year, the undesirable result figure raised up to $50 \%$. This reflected that most students were less proficient in translation, could not integrate English knowledge into the translation well. Therefore, it was absolutely necessary for the instructor to find out the causes, identified the students' weakness, and conveyed the possible solutions which were beneficial in teaching and learning process.

Grammatical knowledge is always being the main errors in translating that presented in the error analysis in translation articles. With various components of error, the instructor has to spot what types of errors are, so the solution can be focused on point. Translation process is also a proper assumption causes the errors in translation. [4] These concepts support the researcher's observations and experiences leading to do this research to clarify what types of errors that occurred in Translation English into Thai class.

\subsection{Objectives}

1) analyze language errors in translating articles from English to Thai

2) analyze causes of errors in article translation

3) find out solutions in instruction to reduce language errors in translation

\subsection{Research Question}

1) What are the characteristics of error in translation articles from English into Thai?

2) What are the causes of error?

3) How can we reduce these errors?

\section{LITERATURE REVIEW}

\subsection{Errors Analysis}

The concept of translation had been formerly regarded as an art or a craft, and develop to considered as a science and admitted as a 
branch of applied linguistics. [5] The models to classify the translation errors are flexible. Therefore, there are various categories of errors found in researches.

Pojprasat (2007) divided translation errors, from his studies in translation from English to Thai and Thai to English, into three characteristics which are semantic errors, syntactic errors and cultural errors. Semantic errors refer to any mistranslation of words such as a single word, collocations, and idioms. Syntactic errors mean mistakes or faults occurred in sentence structure or grammatical structure translation. Culture errors are the effects of cultural differences. [6]

Suksaeresup and Thep-Ackrapong (2009) researched about the errors found in translating English to Thai and categorized the translation errors into two types with their secondary items as presented in the following.

1. The reading of the English text

1.1 Miscue

1.2 The translator's unclear background knowledge

2. English lexical meaning

2.1 Errors in propositional meaning

2.2.1 Wrong alternative meaning of word

2.2.2 Incorrect part of Speech

2.2 Errors in translating expressive meaning

2.2.1 Translating idiomatic expressions after their proposition meaning

2.2.2 Translating term of address after their proposition meaning [7]

Wongranu (2017) divided translation errors in his study into 3 kinds: semantic errors, syntactic errors, and cultural errors. Semantic errors conclude all mistranslation of words: single word, collocations, or idioms. Syntactic errors relate errors in translating sentences, structures or grammar. The cultural error is a mistake in understanding the culture of translators caused by cultural differences. [8]

\subsection{Process of Translation}

Errors in translation mostly result from non-equivalence between the source text and target text in various points related to words, collocations, idioms, sentence structure, grammars, culture, and etc. The process of translation or the way to transfer from one language in to another language cannot be ignored.

Bathgate (1981) revealed that the process of translation consists of seven important steps:

1. Tuning means getting the feel of the text to be translated. Register depends on field of work in the source text.

2. Analysis means the way that the translator tries to analyze the connection of words and sentence structure in the source text.

3. Understanding, the translator interprets the message on the same tone and emotion of the source text base on his basic knowledge of the subject matter.

4. Terminology is focusing on the important words and phrases in the sentence to make sure that apart from understanding them and feeling what they imply and they are transferred in the target language without misleading, ridiculous or offensive words or sentences.

5. Restructuring means rebuild or revise translated text accordance with good usage in the target language.
6. Checking is to proof and revise the translated text by the translator himself and peer to get rid of language errors or typing errors in the target text

7. Discussion between the translator and the expert on the subject matter for sharing experience and suggestion. [9]

Saibua (1997) stated useful specific steps in the translation process to enhance effective translation as following:

1. Do comprehensive study on the source text in message, content, meaning, tone, flavor, and feeling between the lines.

2. Analyze the source text meaning carefully in order to transfer it as accurately as possible. 3 . Transfer the source text into the target language as follows:

Step 1: Define the translation purposes and choose the translation approach.

Step 2: Analyze the source language sentences and transfer them into the target language.

Step 3: Recreate the analyzed sentences to be naturally close to the target language with the similar original meaning, tone and style.

Step 4: Check the translated text whether it is equivalent to the original text.

4. Recheck the correctness of the translated text for quality assurance with peer. The aim of this step is to check whether or not the reader responds equivalently to the translation as they do with the source text in meaning, style, register, and tone. [10]

Pinmanee (2012) suggested 3 steps of translation process: understanding, deverbalization, and re-expression.

First is a step of understanding. It means that the translator uses all dimensions of the source language to interprets and summarizes the meaning of source text with background knowledge related to the text. A good background knowledge can support the translator understand the intended meaning of the source text well.

Second is deverbalization. The translator needs to concentrate on the meaning of the source text without the interference of language structure. It encourages the translator ready to repeat the meaning with the target language.

Last is re-expression. The translator compiles language knowledge, experience and background knowledge to retain the meaning of the source text and expresses naturally close to the target text. [11]

The researcher applied these concepts as the framework of data collection tool.

\section{METHODOLOGY}

\subsection{Research Design}

This was a quantitative research that focused on the frequency of errors found in translating articles, and inconsequential step occurred in translation process.

\subsection{Scope of the Study}

This research focused on article translation which was based on the course description. In addition, there were some limitations in terms of time and learners' experience. The two articles from public resources, which are the authentic material, were selected 
for this study. The content was in accordance with learners' ways of lives and cultural background. That's why we focused on semantic and syntactic errors not the cultural errors in this research. These two topics were "14 Foods that Cleanse the Liver" [12] which was related to basic scientific knowledge in our daily life, scientific technical terms. Another topic was about arts and culture in Thailand, its title was "What Is Thai Silk Really?". [13] The vocabulary and structure of sentences in these articles were in level B1-B2 of the Common European Framework of Reference for Languages (CEFR). The different topics could enable learners notice the differences in the translation errors and process.

\subsection{Sampling Group}

The sampling group was 30 students studying in Translation English into Thai course in the second semester of 2018 academic year. They were the 3rd year students majoring in English for International Communication in Rajamangala University of Technology Suvarnabhumi. They were randomized with the purposive sampling technique and admired to participate in the study. All of them have to passed the pre-requisite course, Basic Translation, so they experienced in translating short excerpt messages and have background of translation.

\subsection{DATA COLLECTION}

Data collections were divided into 2 parts. The first set was collected from 60 papers of assignments related to 2 articles with scientific content, and arts and cultural content with the Analyzation Form of Translation Error recorded by the researcher. The second one was collected from the sample with the Questionnaire about Students' Translation Processes to learn about the students' translating step. The questionnaires were distributed to the students for 2 times after they finished their assignments. Descriptive statistics which are mean, percentage, and describing were used to analyze the collected data.

\subsection{Research Tool}

This study consisted of 2 types of instruments: experimental tool which were the selected articles, and data collection tools which were checklist and questionnaire. [14] The way to conduct and evaluate their validity and reliability are follows:

1) Experimental tools: the article excerpts

After the first screening by the researcher, these two articles were evaluated by the experts and administered the try-out test before designing as the exercise. This was conducted to measure the validity, reliability, difficulty level which suited of learners' performance in terms of vocabulary, language use and content. The10 undergraduates who were non-sampling were asked to take this test. The criteria were that 3 students with excellent performance, 4 students with fair performance, and 3 of them with poor performance. Considering from the reading comprehension score that most of them $(80 \%)$ got $82.5 \%$ it revealed that, these two articles were not too difficult to understand and suitable for the sample. If the expression or the text is to understand even to translators themselves, the function of translation then fail to fulfill. [15]

\section{2) Data collection tools}

(1) Analyzation Form of Translation Error: this checklist was used for analyzing the errors in translation in the aspect of semantic and syntactic errors based on the combination of Saibua's and Pinmanee's frameworks. It was used to collect the errors found in the students' assignments.

(2) Questionnaire about Students' Translation Processes

This questionnaire aimed to find out how the learner's process their article translations to reflect the translation process in terms of the suitable techniques and the alignment with the theory. It was a combination of the scholars' idea presented in the literature review.

The steps of constructing these tools were as follows:

1) Studied related documents about analyzing the errors in translation.

2) Identified the objectives of the research instruments used for collecting data.

3) Construct the tools

3.1) Analyzation Form of Translation Error was the checklist that identified 7 errors in translation with additional suggestions or comments provided.

3.2) Questionnaire about Students' Translation Process required learners to evaluate seven questions about the sequences in process of translation whether they did it or not. An open-ended question was prepared for learners to provide some additional feedback or suggestions.

4) These two data collection instruments were validated by the experts in field in terms of Index of Item-Objective Congruence (IOC). The evaluated results were 0.66-1.00.

\section{RESULTS AND DISCUSSIONS}

The findings can be presented in 3 parts as follows: characteristics of errors in translation, causes of error and the solution guidance.

1) The characteristics of error in translation articles from English into Thai

\section{Scientific Article Translation}

It was found that syntactic errors were the major issues in translating scientific article. The total number of these errors was higher than semantic errors around 3 times. The remarkable subcategorize errors that found in the target text were Modifier, Dummy Subject and Loan Words consecutively as presented in Table 1 . 
Table 1 Errors in Translating Scientific Article "14 Foods that Cleanse the Liver"

\begin{tabular}{|c|c|c|c|}
\hline No. & Type of Errors & Frequency & Percentage \\
\hline $\mathbf{A}$ & Syntactic Errors & & \\
\hline 1 & Determiner & 72 & 8.79 \\
\hline 2 & Dummy Subject & 95 & $11.60^{*}$ \\
\hline 3 & Gerund & 80 & 9.77 \\
\hline 4 & Indefinite pronouns & 52 & 6.35 \\
\hline 5 & Modifier & 148 & $18.07 *$ \\
\hline 6 & Relative Clause & 65 & 7.94 \\
\hline 7 & Tense & 62 & 7.57 \\
\hline 8 & Voice & 71 & 8.67 \\
\hline $\mathrm{B}$ & Semantic Errors & & \\
\hline 9 & Confusing Word & 63 & 7.69 \\
\hline 10 & Connective word & 19 & 2.32 \\
\hline 11 & Loanword & 85 & $10.38^{*}$ \\
\hline 12 & Phrasal Verb & 7 & 0.85 \\
\hline & Total & 819 & 100.00 \\
\hline
\end{tabular}

The students usually placed the modifiers in wrong places or orders especially the word which was modified with different types of adjectives or extended in the complicated form. The modifiers functioning as adjective in Thai are always placed after the main word or noun, in contrast with the modifiers in English which are placed in front of noun and describes any characteristics. If the students, in translation, did not take any notice of Thai grammar and followed the sequence of words in source text, the errors could be occurred. Moreover, in case of complicated modification, some words might be lost in the target text as shown in Table 2.

Table 2 Sample of Modifier Errors

\begin{tabular}{|c|c|c|}
\hline $\begin{array}{c}\text { Source } \\
\text { Text }\end{array}$ & Student's Translation & Correct $\mathrm{T}$ \\
\hline $\begin{array}{l}\text { A small } \\
\text { glass of } \\
\text { freshly- } \\
\text { squeezed } \\
\text { grapefruit } \\
\text { juice }\end{array}$ & $\begin{array}{l}\text { หนึ่งแก้วเล็กของน้ำเกรบฟรุ๊ทที่คั้นสด } \\
\text { - น้ำเกรปฟรุตหนึ่งแก้วเล็กๆ } \\
\text { ที่คั้นสดๆ } \\
\text { - น้ำเกรปฟรุตแก้วเล็กๆ หนึ่งแก้ว }\end{array}$ & นำเกร \\
\hline
\end{tabular}

Next is the Dummy Subject errors. It is always being the notable errors found in Thai students due to their word-to-word translation, and context ignorance. Moreover, the Thai structure sentence consists of subject, verb, and object, so the dummy subject is never skipped in their target text.

\begin{tabular}{|l|l|l|}
\hline $\begin{array}{c}\text { Sourc } \\
\mathbf{e} \\
\text { Text }\end{array}$ & \multicolumn{1}{|c|}{ Student's Translation } & \multicolumn{1}{c|}{$\begin{array}{c}\text { Correct } \\
\text { Translation }\end{array}$} \\
\hline$\ldots$ it's & มันเป็นเวลาทีต้องทำการเปลีย & ถึงเวลาทีต้องปรับเป \\
time & นแปลง & ลี่ยน \\
to \\
make \\
chang
\end{tabular}

The third remarkable error is Loanword. In this scientific article, 14 Foods that Cleanse the Liver, the writer has revealed the beneficial substances contained in fruits and vegetable with the scientific technical terms, transliterating is usually a suitable way. We have to concentrate on the right spellings in Thai and recheck them with the dictionary of the Office of the Royal Society that presents the criteria of foreign word transliteration. However, some foreign words have the meaning written in Thai dictionary and it is used generally, transliteration should not be applied in this case. Some students in this study were sometimes lack of awareness in this issue. The samples are presented in Table 4.

Table 4 Sample of Loanword Errors

\begin{tabular}{|l|l|l|}
\hline \multicolumn{1}{|c|}{$\begin{array}{c}\text { Source } \\
\text { Text }\end{array}$} & $\begin{array}{c}\text { Student's } \\
\text { Translati } \\
\text { on }\end{array}$ & \multicolumn{1}{|c|}{ Correct Translation } \\
\hline $\begin{array}{l}\text { Enzyme } \\
\text { Beta- } \\
\text { carotene } \\
\text { chloroph } \\
\text { yll }\end{array}$ & $\begin{array}{l}\text { เอ็น์, } \\
\text { เบตา- } \\
\text { เคโรทีน } \\
\text { คอโรฟิน }\end{array}$ & $\begin{array}{l}\text { เอ็นไซม์ } \\
\text { เบต้าเคโรทีน } \\
\text { คลอโรฟีลล์ม, } \\
\text { สารสีเขียวที่พบในพืชหรือแบคทีเรียบ } \\
\text { างชนิด }\end{array}$ \\
\hline
\end{tabular}

The last interesting error that found in the raw data collection, but Transfighter in Table 1doesn't look remarkable is Confusing Word. More than ninety percentage of the target text presenting the

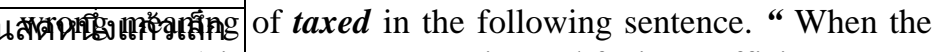
liver is taxed, it can't process toxins and fat in an efficient way." Taxed was tran\$lated to "an amount of money that you must pay to the government" instead of "to make the liver have to work hard". From the class discussion, some students accepted that they knew only a meaning of tax as a noun. The other said that they noticed the verb, taxed, in form of passive voice, so "paid the money to the government" was selected without consulting dictionary and context. This point also presents the difference of Thai and English words. A Thai word, in general, has one meaning and one form, in contrast, an English word sometimes has more one meanings and forms. This could mislead the translator into doing a wrong interpretation.

Table 3 Sample of Dummy Subject Errors 
Arts and Culture Article Translation

The notable errors found are two items of syntactic errors: modifier and voice; one of semantic errors, confusing word as shown in Table 5.

Table 5 Errors in Translating Arts and Culture Article "What is Thai silk really?"

\begin{tabular}{|c|c|c|c|}
\hline No. & Type of Errors & Frequency & Percentage \\
\hline $\mathbf{A}$ & Syntactic Errors & & \\
\hline 1 & Determiner & 55 & 7.89 \\
\hline 2 & Dummy Subject & 17 & 2.44 \\
\hline 3 & Gerund & 28 & 4.02 \\
\hline 4 & Indefinite pronouns & 46 & 6.60 \\
\hline 5 & Modifier & 111 & $15.93^{*}$ \\
\hline 6 & Participle & 46 & 6.60 \\
\hline 7 & Relative Clause & 65 & 9.33 \\
\hline 8 & Tense & 61 & 8.75 \\
\hline 9 & Voice & 89 & $12.77 *$ \\
\hline B & Semantic Errors & & \\
\hline 10 & Confusing Word* & 103 & $14.78^{*}$ \\
\hline 11 & Connective word & 61 & 8.75 \\
\hline 12 & Phrasal Verb & 15 & 2.15 \\
\hline & Total & 697 & 100.00 \\
\hline
\end{tabular}

Modifier errors were in the highest rank of both articles, due to word order as mentioned above. It is a big problem of Thai students facing to English language influence and their unawareness of the syntactic difference. Adverb of time in Thai could be placed in a more adjustable position than an adjective and other kinds of adverb depending on contexts. When we want to narrate about the past, an adverb of time could be placed at the beginning of the sentence for example "กาลครั้งหนึ่งนาน มาแล้ว ยังมีเด็กผู้หญิงคนหนึ่ง" means "once upon a time, there was a little girl...". The samples are shown in Table 6

Table 6 Sample of Modifier Errors

\begin{tabular}{|c|c|c|}
\hline $\begin{array}{c}\text { So } \\
\text { urc } \\
\text { e } \\
\text { Te } \\
\text { xt }\end{array}$ & $\begin{array}{c}\text { Student's } \\
\text { Translation }\end{array}$ & Correct Translation \\
\hline $\begin{array}{l}\text { Tr } \\
\text { uly } \\
\text { it } \\
\text { is } \\
\text { an } \\
\text { exc } \\
\text { lusi } \\
\text { ve }\end{array}$ & $\begin{array}{l}\text { จริงๆ } \\
\text { แล้วผ้าไหมเป็นผ้าที่มี } \\
\text { ความพิเศษอย่างมาก } \\
\text { และเมื่อในอดีตมันมี } \\
\text { ว้สำหรับชนชั้นสูงและ } \\
\text { กษัตริย์เท่านั้น }\end{array}$ & $\begin{array}{l}\text { ผ้าไหมเป็นผ้าทีมีความพิเศษอย่ } \\
\text { างยิ่ง } \\
\text { เมื่อมองย้อน ไปในอดีตผ้าไหมจะ } \\
\text { สงวนไว้สำหรับกลุ่มของชนชั้นสู } \\
\text { งและกษัตร์ย์เท่านั้น }\end{array}$ \\
\hline
\end{tabular}

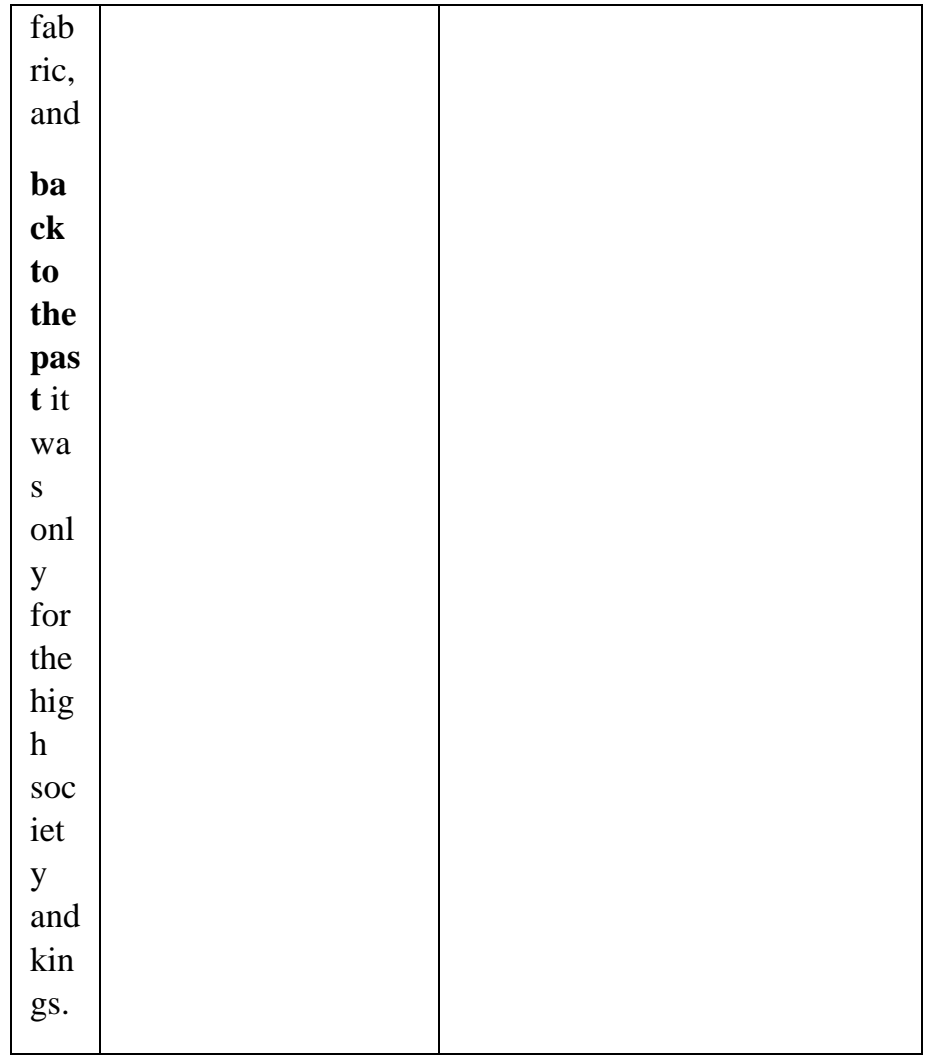

Voice errors were the third frequently found among another errors. Passive Voice errors were generally seen in these translated texts without the awareness of Thai structure and meaning. Active voice is always used in Thai except communicating some negative messages such as "He was arrested yesterday." It's quite difference that passive voice in English is also used to convey the processes or means of making or doing something as shown in "What is Thai silk really?" The translators, in fact, should aware how to transfer the text with correct structure of active voice in Thai.

Table 7 Sample of Voice Errors

\begin{tabular}{|l|l|l|}
\hline So & Student's Translation & Correct Translation \\
ur & & \\
Te & & \\
xt & & \\
\hline $\mathrm{Pu}$ & ไหมแท้ถูกทำด้วยเส้นด้ายแ & ไหมไทยแท้จะทอด้วยด้าย \\
$\mathrm{re}$ & นวตั้งและเส้นด้ายแนวนอน & ยืนและด้ายพุ่งสีต่างกัน \\
$\mathrm{Th}$ & & ไหมไทยแท้จะทอด้วยด้าย \\
$\mathrm{ai}$ & & ยืนและด้ายพุ่งคนละสี \\
sil & ไหมแท้ไม่สามารถได้รับกา & \\
$\mathrm{k}$ & รปฏิบัติเหมือนกันผ้าลินินแ & \\
is & ละผ้าฝ้าย & \\
ma & & \\
de & & \\
\hline
\end{tabular}




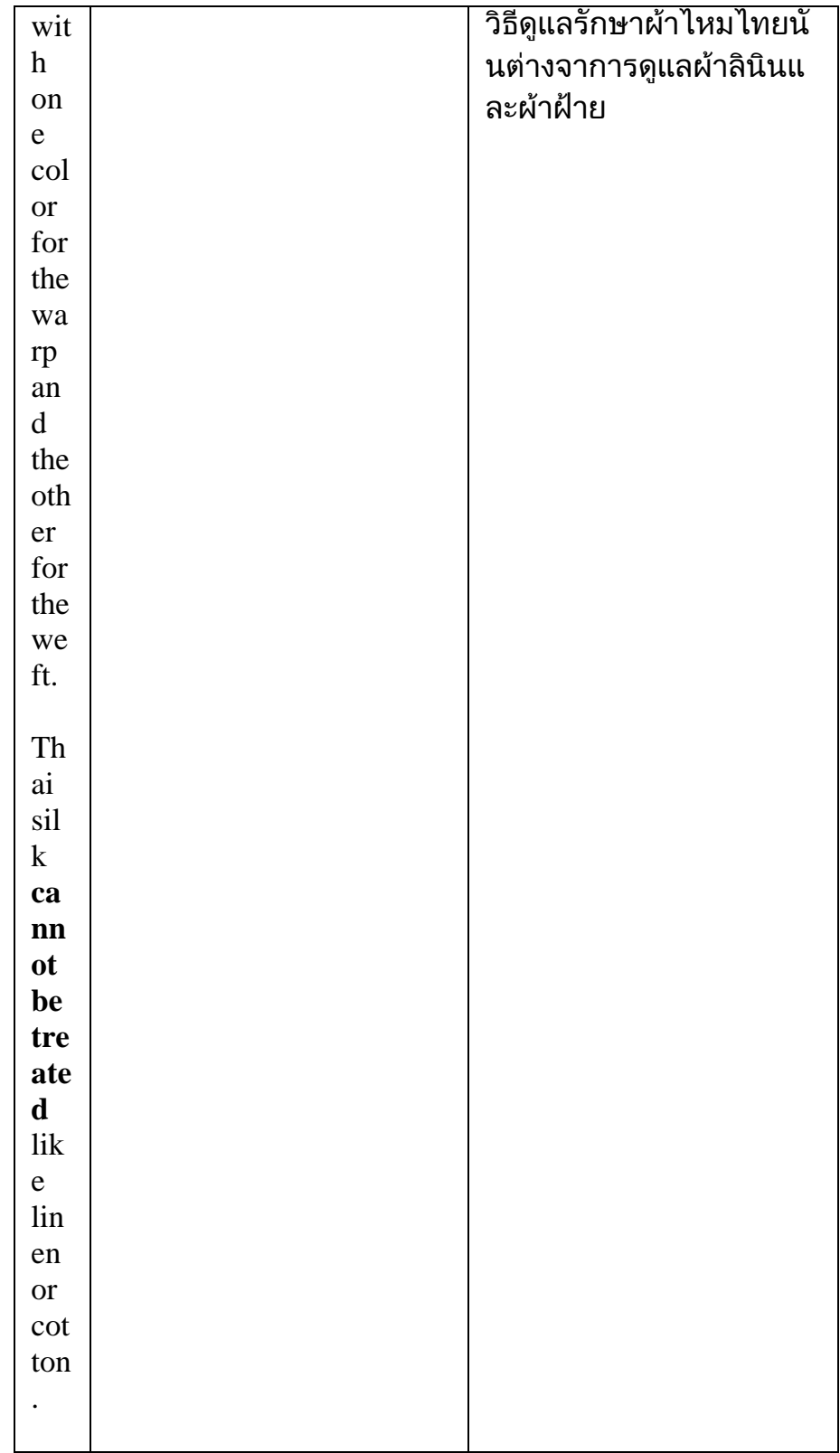

Confusing Word Errors was still in a high rank. It always occurred when the students translated their daily life words. They were very confident that their translated word was right and fit into the context. As the above mention, the dictionary was not used to determine which meaning of a multiple-meaning word was correct in a sentence alike the example in Table 8. Most students translated the word "found" to " find" or "พบ" instead of the correct meaning "established" or "กระทำ"

Table 8 Sample of Confusing Word Errors

\begin{tabular}{|c|l|l|}
\hline $\begin{array}{c}\text { Sour } \\
\text { ce } \\
\text { Text }\end{array}$ & \multicolumn{1}{|c|}{ Student's Translation } & Correct Translation \\
\hline $\begin{array}{l}\text { Anyo } \\
\text { ne } \\
\text { foun }\end{array}$ & $\begin{array}{l}\text { ใครก็ตามทีพบความผิดเกี } \\
\text { ยวกับการขโมยไข่ไหม }\end{array}$ & $\begin{array}{l}\text { ใครก็ตามทีกระทำความ } \\
\text { ผิดฐานขโมยไข่ไหม }\end{array}$ \\
\hline
\end{tabular}

This publication is licensed under Creative Commons Attribution CC BY. http://dx.doi.org/10.29322/IJSRP.10.07.2020.p10380

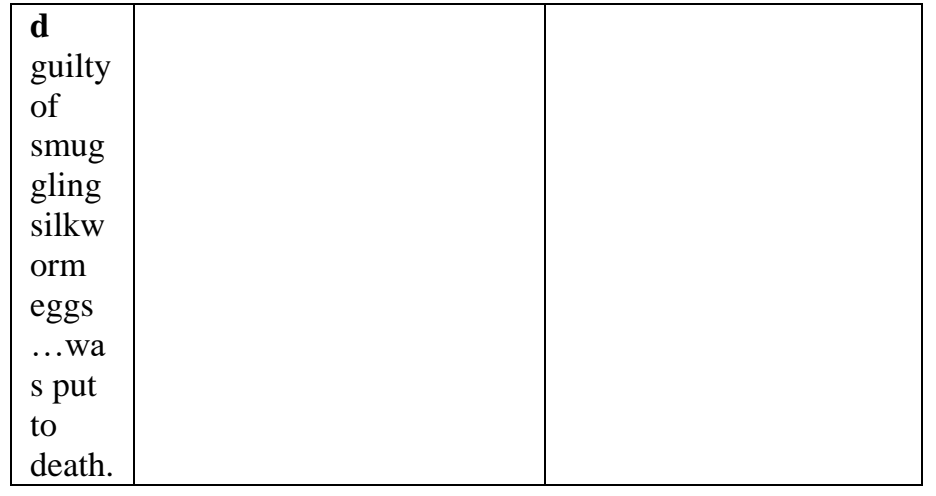

It could be concluded that main factors causing errors in translation were syntactic knowledge in English and Thai; semantic knowledge, particularly in multiple-meaning words and connotation; errors awareness. In this research, the process of translation was studied whether it was a cause of errors. The result is presented in Table 9.

Table 9 Steps in Process of Article Translation

\begin{tabular}{|l|c|c|}
\hline \multicolumn{1}{|c|}{ Step in Translation Process } & $\begin{array}{c}\text { Frequency } \\
\text { (N=30) }\end{array}$ & Percentage \\
\hline 1. read and understand the article & 23 & 76.67 \\
\hline $\begin{array}{l}\text { 2. translate to the target text, the } \\
\text { first draft }\end{array}$ & 30 & 100 \\
\hline \begin{tabular}{l} 
3. consult dictionary \\
\hline $\begin{array}{l}\text { 4. do the research on knowledge } \\
\text { background related to the } \\
\text { article }\end{array}$
\end{tabular} & 30 & 100 \\
\hline $\begin{array}{l}\text { 5. check and revise the first draft } \\
\text { by yourself }\end{array}$ & 7 & 36.67 \\
\hline $\begin{array}{l}\text { 6. discuss and do peer review } \\
\text { 7. do the final revise before } \\
\text { submitting }\end{array}$ & 23.33 \\
\hline
\end{tabular}

The data reveal that the students always proceeded in their translation by consulting a dictionary and making a first draft of translated paper. They usually read and understood the article. Someone did the research on knowledge background related to the article. The students themselves hardly checked and revised their first draft; discussed with their friends; did the final revise before submitting.

From the additional discussion, the students agreed that they skipped the important steps: checking and revising because of the short-provided period of time. They ensured that running the 
translation process step by step could support their translation skills and good texts. They also thought that their vocabulary bank in English and Thai should be developed to reduce their misinterpretation of the English lexical meaning.

These were the guidance of the last question in this study that how we can reduce these errors in the students' opinions. Moreover, the length of text should be related to the provided time. The additional exercises of each specific errors should be created. The process of translation should be simulated in class.

\section{Conclusion}

The conclusion of the research is grammatical knowledge and translation process played the significant roles in translating articles from English into Thai. To be skilled in translation, the students' self-awareness about their strength and weakness is the main factor. In the further studies, investigating the factors affecting English into Thai translation in the different texts such as tales, news or short story is interesting. The result comparisons will suggest weakness and strength of the students' translation skills that could be reduced or improved with the suitable techniques and strategies.

\section{REFERENCES}

[1] Thep-Ackrapong, T. 2011. Basic Translation. Bangkok: Chulalongkor University Press.

[2] Pinmanee, S. 2012. Translation: from Wrong to Right. Bangkok: Chulalongkorn University Press.

[3] Faculty of Liberal Arts. 2013. Bachelor of Liberal Arts Program in English for International Communication. Rajamangala University of Technology Suvarnabhumi. Ayutthaya. (copied).
[4] Kartini Rahmatilah. 2013. "Translation Errors in the Process of Translation," Journal of English and Education, Vol. 7 No.1-June 2013 p.14-24.

[5] Nord, C. 1997. Text Analysis in Transaltion: Theory, Methodology and Didactic Application of Model for Translation-Oriented Text Analysis. Amsterdam: Rodopi.

[6] Pojprasat, S. 2007. An Analysis of Translation Errors made by Mattayomsuksa 6 students. Srinakharinwirot University. Bangkok.

[7] Suksaeresup and Thep-Ackrapong. 2009. Lost in Translation:How to Avoid Errors in Translation from English. Translation Journal. Vol.13, No.1. Retrieved on May 2018 from https://translationjournal.net/journal/47 errors.htm.

[8] Wongranu, P. 2017. Errors in translation made by English major students: A study on types and causes. Kasetsart Journal of Social Sciences 38.

[9] Bathgate, R.H. 1981. "Studies of Translation Models 2: A Theoretical Framework", in The Incorporated Linguist, Vol. 20, 1, 10-16

[10] Saibua, S. 1997. Principle of Translation. (6th ed) Bangkok: Thamasart University Press.

[11] Pinmanee, S. 2009. Advance Translation. Bangkok: Chulalongkorn University Press.

[12] Bettermann, E. 2017. 14 Foods that Cleanse the Liver. Retrieved on June 2018 from https://dreddymd.com/2017/01/19/14-foods-that-cleanse-theliver/.

[13] Wisser, D. 2007. What Is Thai Silk Really? Retrieved on June 2018 from https://www.fibre2fashion.com/industry-article/1445/what-is-thai-silk-really

[14] Maneechoti, T. "Research Instruments" from Research Learning Center of Thailand. http://www.rlc.nrct.go.th/ewt_dl.php?nid=1144.

[15] Wilss, W. 1982. The Science of Translation: Problems and Methods. Tubigen: Gunter.

\section{AUTHORS}

First Author - Palarak Chaiyo, Ed.D, Faculty of Liberal Arts, Rajamangala University of Technology Suvarnabhumi Email address: palarak@gmail.com 